\title{
Assessing Cold Hardiness of Red Raspberry Genotypes in the Laboratory and Field
}

\author{
Annette M. Zatylny, J.T.A. Proctor, and J.A. Sullivan \\ Department of Horticultural Science, University of Guelph, Guelph, Ontario, N1G 2W1, Canada
}

Additional index words. Rubus idaeus, conductivity, tissue browning, controlled freezing, cane dieback

\begin{abstract}
Tissue survival assessments of red raspberry (Rubus idaeus L.), including cane dieback, bud death, time of cane leaf drop, and growth cessation, were compared to freezing tests of stem portions and buds. Four named cultivars and six Guelph (designated Gu) selections were assessed in the field at two locations in each of two winters and in concurrent controlled freezing tests at one location for one winter. The time of cane leaf drop and of cessation of cane extension growth in the fall were not correlated with field survival. Cane dieback as a percentage of cane length was a better estimate of winter survival than was bud number. Controlled freezing tests of stem portions and buds, and calculation of $T_{40} S$ and $T_{50} s$ indicate that genotypes differed in their relative hardiness throughout the winter. The different methods of field assessment of cold hardiness were well correlated, but not well correlated with controlled freezing tests (4.2\% significant correlations). Exclusion of the genotype, $\mathrm{Gu} 75$, which behaved differently in the field than in freezing tests, increased the number of significant correlations to $16.7 \%$.
\end{abstract}

There is an increasing global interest in raspberry cold hardiness. Because of economic losses there is a need to stabilize production and extend cultivation to more northerly environments (Hummer et al., 1995).

Biennial canes of summer fruiting red raspberry are susceptible to winter injury. Cane dieback due to winter injury in raspberries reduces yield (Fejer and Spangelo, 1973). Winter survival is a highly complex phenomenon (Quamme and Stushnoff, 1983) and accurate assessment of plant hardiness is difficult.

An assessment of winter injury during the subsequent growing season is commonly used to determine cold hardiness. However, this type of hardiness determination is complicated by the variability that exists among locations and years (Stushnoff, 1972), thus several seasons are required to accurately determine relative winter hardiness among genotypes.

Early acclimation in the fall is crucial for red raspberry (Brierley and Landon, 1946; Jennings et al., 1972; Van Adrichem, 1970). Indicators of early acclimation may prove useful in ranking cultivars for cold hardiness. Acclimation patterns of raspberry canes have been related to a number of factors associated with early cane maturity. A few reports associate an early growth cessation or a slowing of extension growth in the fall with greater cane survival (Fejer, 1973; Van Adrichem, 1966 and 1970). The time of leaf drop has also been investigated as an indicator of cold hardiness in raspberries, however, results are not consistent. Early leaf drop was not a reliable indicator of winter hardiness (Fejer and Spangelo, 1973), nor did it have a positive relationship with winter injury (Van Adrichem, 1970).

To circumvent the need for several seasons of field testing, controlled freezing tests are widely used to assess cold tolerance. Several methods are available to assess injury of the plant material after it has been subjected to freezing stress. Among the most common are the conductivity method and a rating of tissue browning. Freezing stress results in membrane damage causing the leakage of cellular electrolytes (Quamme and Stushnoff, 1983). The conductivity method measures the electrical conductivity of

Received for publication 1 June 1995. Accepted for publication 10 Aug. 1995. This research was supported by operating grant no. A6697 of the Natural Sciences and Engineering Research Council of Canada held by J.T.A.P. We gratefully acknowledge the assistance of Glen Lumis, Dean Louttit, Deborah Buszard, and Jean Pierre Laplaine. The cost of publishing this paper was defrayed in part by the payment of page charges. Under postal regulations, this paper therefore must be hereby marked advertisement solely to indicate this fact. the plant extract providing an estimate of cellular leakage and thus membrane damage from cold injury (Levitt, 1980). Low temperature injury also results in tissue browning due to the oxidation of polyphenols in the cell (Sakai and Larcher, 1987). The degree of browning can be assessed visually and given a numerical rating (Quamme and Stushnoff, 1983).

The objective of this study was to compare cold hardiness plant and tissue tests with controlled freezing tests using red raspberry genotypes.

\section{Materials and Methods}

Field survival. Studies were conducted to assess the ability of field measurements and controlled freezing tests to differentiate hardiness of red raspberry genotypes. The field study was conducted over 2 years, 1988-89 and 1989-90, and at two locations, the Cambridge Research Station (CRS) of the Univ. of Guelph, Cambridge, Ontario; and at Macdonald Campus of McGill Univ., Ste. Anne de Bellevue, Quebec (referred to as the Montreal location).

Six raspberry selections (designated the Gu series) from the Univ. of Guelph raspberry breeding program and four named cultivars of known hardiness were planted as a randomized complete block with five blocks in Spring 1988 at Montreal and CRS. Plants were trained in a hedge-row system. The standard cultivars selected were 'Boyne' (Ure and Morrison, 1962) and 'Comet' (Brooks and Olmo, 1972), which were considered 'hardy' based upon previous recorded field performance; and 'Chilcotin' (Daubeny, 1978) and 'Comox' (Daubeny, 1987), which were rated as having intermediate hardiness by Daubeny $(1978,1987)$ but are referred to as non-hardy in this study. 'Chilcotin' and 'Comox' were bred and selected for the environment of the Pacific Northwest and do not possess hardiness levels suitable for the harsher winters of eastern Canada. The Gu series has been screened over several winters at Cambridge Research Station (CRS) and in vitro (Zatylny et al., 1993) and consistently shows high levels of winter hardiness. Two selections, Gu74 and Gu75, have been named OAC Regal and OAC Regency, respectively (Cummins, 1994).

Measuring winter injury. At the two locations in both years, winter injury was measured using three different characters: 1) percent cane dieback from the tip as measured on the basis of cane length and bud number, 2) percent bud death within the cane midportion (the midportion of the cane was considered that portion 
below the cane dieback to the most distal lateral), and 3) percent bud death of the total cane (dieback plus mid-portion of the cane). Dead bud counts also included those buds that may have leafed out in the spring but died later in the season without producing a fruiting lateral.

Cane dieback was recorded from four and six floricanes (randomly selected) in each plot in Summer 1989 and 1990, respectively. Data on bud death were collected from two and four canes within a plot in 1989 and 1990, respectively. The mean values from each plot were used in the analysis of variance.

Measuring cane maturity. Cane maturity was measured as the time of cessation of cane extension growth and the time of leaf drop. Data on the time of cessation of cane extension growth were obtained from plots at CRS in the fall of 1989. A representative cane from each of the plots at CRS was selected on 21 Aug. 1989, was tagged $10 \mathrm{~cm}$ below the apex as a reference point, and was measured for growth at weekly intervals. The date of growth cessation was recorded as the first of three successive dates when cane elongation remained unchanged. Leaf drop was recorded weekly in the fall of 1988 and 1989 from a representative cane selected from each plot at CRS. The time of leaf drop was recorded as days from 1 Sept. until half of the leaves in the upper third of the cane had abscised.

Statistical analysis. The treatments were arranged in a factorial experiment, with two locations (acting as blocks), 10 genotypes, 2 years and 5 replicates within a location. Year was considered a random effect.

All data were subjected to an analysis of variance and a least square means (lsmeans) multiple comparison procedure (SAS Inst., Cary, N.C.) Orthogonal contrasts were conducted on winter survival data to compare genotype groupings. Before analysis, the data were transformed by either a log, square root, or arcsine transformation where appropriate.

Genotype rankings produced by the various measurements of winter injury at the three locations were compared using Kendall's rank correlation $(\tau)$ procedure. A one-sided probability test $(P=$ 0.05 ) for a positive correlation was used unless otherwise stated.

\section{Controlled freezing tests}

Preparation. Controlled freezing experiments were conducted throughout the fall and winter of 1989-90 on raspberry canes of the 10 genotypes used in the field study. Canes were collected from established research plots (randomized complete-block design) at the CRS.

The midportions (about $40 \mathrm{~cm}$ in length) of eight canes of each genotype were collected on selected (see Fig. 1) dates commencing October 1989 until April 1990. Canes were tied in bundles, placed in polyethylene bags, and transported to a freezer maintained at a control temperature to approximate outdoor temperature at the time of sampling. The freezer was capable of freezing at a specified constant cooling rate to a minimum of about $-32 \mathrm{C}$. A constant rate of cooling of the freezer was obtained using time clocks connected to an electric motor which regulated the opening of an evaporator pressure regulator valve.

The experiment was set up as a completely randomized design with 4 replicates. For each of the 10 genotypes and dates, 4 of the 8 canes were used for the conductivity experiment, and the remaining 4, for the visual assessment of oxidative browning. For the conductivity experiment, a cane section was cut into 10 internodal pieces each about $1.5 \mathrm{~cm}$ in length, varying according to the internodal lengths along the cane. Canes used for the visual assessment were cut into 10 pieces, each containing at least one bud and a section of stem. Each cane piece for both experiments
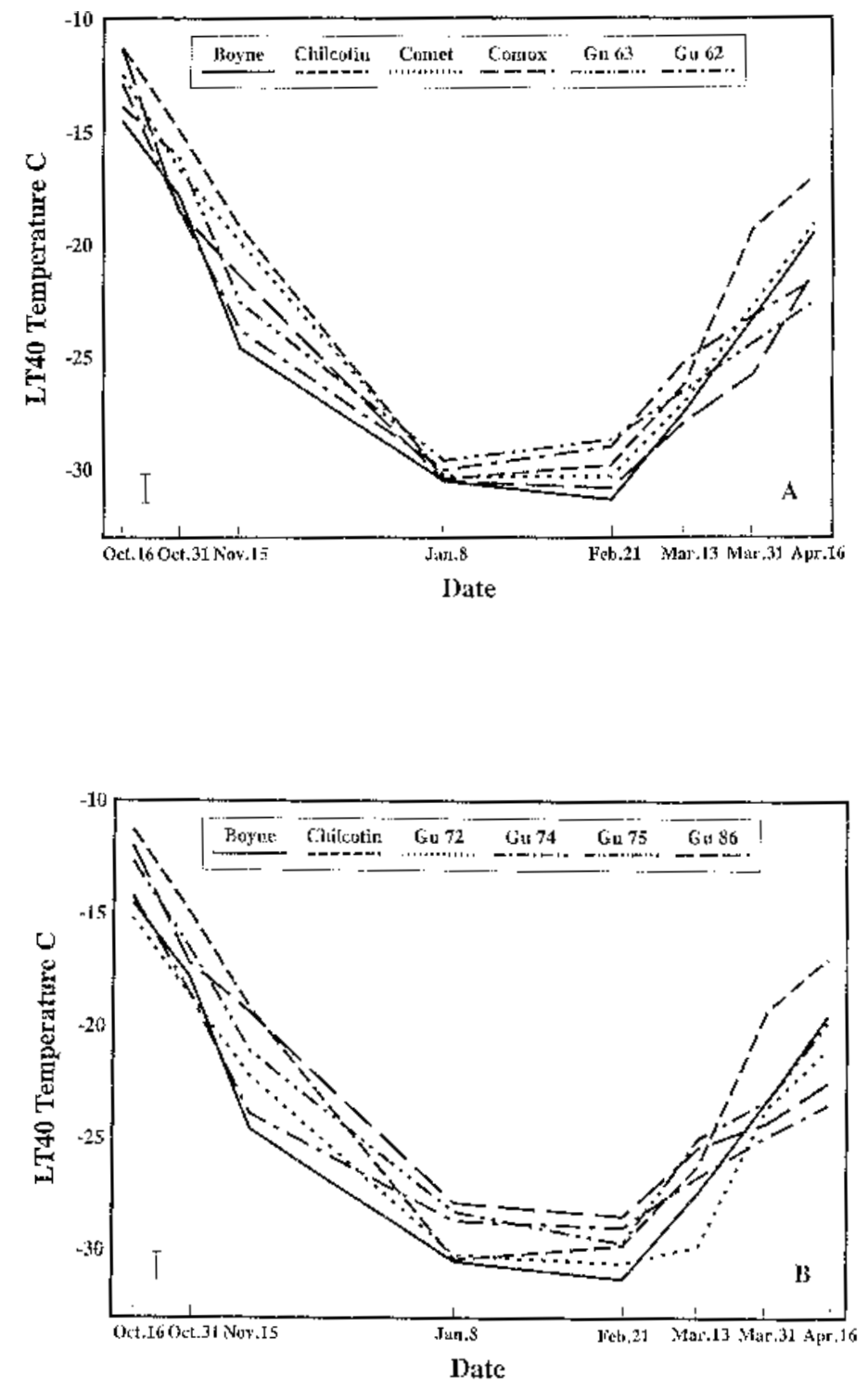

Fig 1. Mean $\mathrm{LT}_{40} \mathrm{~s}$ of stems of 10 raspberry genotypes after controlled freezing and visual assessment of tissue browning, CRS, 1989-90. The bar on each graph (bottom left) represents the minimum difference required for significance between two means at a comparison wise error rate of $\alpha=0.05$.

was moistened by dipping in deionized water, placed into a test tube, and capped. Samples were held overnight in the freezer which was set to approximate the outdoor temperature at the time of collection.

Freezing. The following morning, a set of tubes was removed from the freezer and designated as the live controls. The freezer temperature was then lowered at a rate of $4 \mathrm{C} / \mathrm{h}$. Sets of tubes were removed from the freezer when the desired treatment temperatures were reached. After the freezer reached its lowest temperature, one set of tubes was placed in another freezer at $-76 \mathrm{C}$ for $1 \mathrm{~h}$. The samples killed at $-76 \mathrm{C}$ served as dead controls.

Assesing conductivity. For the conductivity experiment, all tubes were removed from the freezer, including the live and 'dead' controls. The tubes were allowed to thaw for $2 \mathrm{~h}$ at room temperature and then $20 \mathrm{ml}$ of deionized water were added to each tube. After soaking for $22 \mathrm{~h}$, the tubes were shaken and the conductivity of the leachate was measured with a YSI conductivity bridge, model 31 (Fisher Scientific, Toronto, Ont.). Test tubes still con- 
taining the tissue sample and water solution then were autoclaved to ensure complete kill of the tissue. After removal from the autoclave, test tubes were allowed to stand for another $22 \mathrm{~h}$ when conductivity was measured again. For each sample, percent leakage was calculated as follows:

$\%$ leakage $=($ conductivity after freezing/conductivity after autoclaving) $\times 100$

Visual assessment. Samples used for the visual assessment were allowed to thaw at room temperature after removal from the freezer and remained at room temperature for one week to allow for tissue browning to occur. They were then placed in a refrigerator (at 3C) for at least one more week when they were assessed for oxidative browning. Small amounts of deionized water were added to the test tubes as required to prevent desiccation of the samples. Buds and stems were sectioned longitudinally and each given a tissue damage rating of 1 (<1/3 browning), 2 (1/3-2/3 browning), 3 (>2/3 almost complete browning) or 4 (complete browning).

Statistical analysis. For the conductivity experiment, percent damage was calculated as follows:

$\%$ damage $=\left(\%\right.$ leakage $_{\mathrm{T}}-\%$ leakage $_{\mathrm{LC}} / \%$ leakage $_{\mathrm{DC}}-\%$ leakage $\left._{\mathrm{LC}}\right)$ $\times 100$

where $\mathrm{T}=$ temperature, $\mathrm{LC}=$ live control and $\mathrm{DC}=$ dead control

The remaining analysis is similar to that described by Khanizadeh et al. (1989) in which the regression of percent damage on temperature for each cane of each date and cultivar was calculated to obtain the regression parameters of intercept and slope to calculate the lethal temperature. The median lethal temperature (MLT or $\mathrm{LT}_{50}$ ) is most commonly used; however, in this study, the $\mathrm{LT}_{40}$ (the temperature at which $40 \%$ injury occurred) was used mostly because $50 \%$ injury did not always occur at the freezer's lowest temperature of $-32 \mathrm{C}$. The $\mathrm{LT}_{50}$ has been estimated, if it could not be calculated to allow comparisons with data in the literature. Lethal temperatures were calculated for each replicate of each genotype and date and subjected to an analysis of variance.

Ratings from the visual assessment of buds and stems were transformed into percentages. The remaining analysis was as for the conductivity method in which the regression parameters of slope and intercept were obtained and the $\mathrm{LT}_{40}$ calculated.

Genotype rankings of cold tolerance on the various dates for the tests involved were compared using Kendall's rank correlation $(\tau)$. A one-sided probability test for a positive correlation was used unless otherwise stated.

\section{Results and Discussion}

Before comparing the field and laboratory methods the ability of each method to differentiate between genotypes is reported.

\section{Field study}

Winterinjury. All measurements of winter injury except for bud death within the mid-portion of the cane allowed determination of genotypic differences without the influence of location and year interactions. When winter injury was measured as mean dieback (length) and mean percent bud number, 'Comox' and 'Chilcotin' had $15.1 \%$ and $6.7 \%$ respectively, more dieback than all other genotypes (Tables 1 and 2). These findings confirm the relative cold tenderness of the Pacific Northwest genotypes in harsher eastern winters. Hummer et al. (1995) also found, in laboratory freezing tests and $\mathrm{T}_{50}$ determinations, that 'Chilcotin' stems were 6 degrees ( -22 vs. $-28 \mathrm{C}$ ) less hardy than 'Boyne'. Bud death over the entire cane was greatest for 'Comox' and 'Chilcotin' (Tables 1 and 3). These assessments suggested the genotype, Gu75, was the hardiest. Based on percent mean bud number, Gu75 was
Table 1. Percent dieback (length and bud number) and total cane bud death of 10 raspberry genotypes averaged for two locations (Cambridge Research Station and Montreal) over two winters (1988-89 and 1989-90).

\begin{tabular}{|c|c|c|c|}
\hline \multirow[b]{2}{*}{ Genotypes } & \multicolumn{2}{|c|}{ Dieback } & \multirow{2}{*}{$\begin{array}{c}\text { Total cane } \\
\text { bud death }(\%)\end{array}$} \\
\hline & Length $(\%)$ & Bud no. $(\%)$ & \\
\hline$\overline{\mathrm{Gu} 62}$ & $6.3 c^{2}$ & $19.7 \mathrm{~d}$ & $41.0 \mathrm{bc}$ \\
\hline Gu 63 & $5.8 \mathrm{c}$ & $15.7 \mathrm{~cd}$ & $39.2 \mathrm{bc}$ \\
\hline Gu 72 & $6.2 \mathrm{c}$ & $14.4 \mathrm{c}$ & $32.3 \mathrm{ab}$ \\
\hline Gu 74 & $5.3 \mathrm{bc}$ & $13.8 \mathrm{c}$ & $31.9 \mathrm{ab}$ \\
\hline $\mathrm{Gu} 75$ & $1.7 \mathrm{a}$ & $5.2 \mathrm{a}$ & $22.3 \mathrm{a}$ \\
\hline Gu 86 & $4.6 \mathrm{bc}$ & $13.4 \mathrm{c}$ & $29.3 \mathrm{ab}$ \\
\hline Boyne & $3.1 \mathrm{ab}$ & $8.4 \mathrm{~b}$ & $31.0 \mathrm{ab}$ \\
\hline Comet & $6.8 \mathrm{c}$ & $15.6 \mathrm{~cd}$ & $33.6 \mathrm{ab}$ \\
\hline Chilcotin & $12.0 \mathrm{~d}$ & $24.7 \mathrm{e}$ & $48.4 \mathrm{c}$ \\
\hline Comox & $19.4 \mathrm{~d}$ & $28.0 \mathrm{e}$ & $48.8 \mathrm{c}$ \\
\hline
\end{tabular}

${ }^{\mathrm{z}}$ Mean separation within columns by LSMEANS, $P \leq=0.05$.

Table 2. Percent tip dieback of 10 raspberry genotypes at two locations (Cambridge Research Station and Montreal) for two winters (1988-89 and 1989-90).

\begin{tabular}{|c|c|c|c|c|c|}
\hline \multirow[b]{3}{*}{ Location } & \multirow[b]{3}{*}{ Genotype } & \multicolumn{4}{|c|}{ Dieback } \\
\hline & & \multicolumn{2}{|c|}{ (\% length) } & \multicolumn{2}{|c|}{ ( $\%$ bud number) } \\
\hline & & 1989 & 1990 & 1989 & 1990 \\
\hline \multirow[t]{11}{*}{$\overline{\mathrm{CRS}}$} & $\mathrm{Gu} 62$ & $3.8 \mathrm{~cd}^{2}$ & $5.2 \mathrm{de}$ & $12.6 \mathrm{bc}$ & $18.8 \mathrm{e}$ \\
\hline & Gu 63 & $6.3 \mathrm{de}$ & $2.6 \mathrm{bc}$ & $16.4 \mathrm{c}$ & $9.1 \mathrm{abc}$ \\
\hline & Gu 72 & $5.6 \mathrm{~d}$ & $3.4 \mathrm{bcd}$ & $11.6 \mathrm{bc}$ & $8.0 \mathrm{ab}$ \\
\hline & Gu 74 & $4.8 \mathrm{~cd}$ & $3.1 \mathrm{bcd}$ & $12.3 \mathrm{bc}$ & $10.8 \mathrm{bcd}$ \\
\hline & Gu 75 & $0.2 \mathrm{a}$ & $1.1 \mathrm{a}$ & $0.4 \mathrm{a}$ & $4.2 \mathrm{a}$ \\
\hline & Gu 86 & $2.7 \mathrm{c}$ & $3.3 \mathrm{bcd}$ & $8.2 \mathrm{~b}$ & $10.5 \mathrm{bc}$ \\
\hline & Boyne & $0.9 \mathrm{~b}$ & $1.2 \mathrm{ab}$ & $2.6 \mathrm{a}$ & $6.3 \mathrm{ab}$ \\
\hline & Comet & $3.4 \mathrm{~cd}$ & $7.0 \mathrm{e}$ & $8.3 \mathrm{~b}$ & $18.4 \mathrm{de}$ \\
\hline & Chilcotin & $5.5 \mathrm{~d}$ & $5.0 \mathrm{cde}$ & $17.2 \mathrm{c}$ & $16.0 \mathrm{cde}$ \\
\hline & Comox & $10.9 \mathrm{e}$ & $18.8 \mathrm{f}$ & $14.4 \mathrm{bc}$ & $29.7 \mathrm{f}$ \\
\hline & Mean & 4.4 & 5.1 & 10.4 & 13.2 \\
\hline \multirow[t]{11}{*}{ Montreal } & $\mathrm{Gu} 62$ & $8.8 \mathrm{ab}$ & $9.1 \mathrm{c}$ & 25.4 cde & $23.6 \mathrm{c}$ \\
\hline & Gu 63 & $7.6 \mathrm{ab}$ & $8.5 \mathrm{c}$ & $16.4 \mathrm{abc}$ & $22.5 \mathrm{c}$ \\
\hline & Gu 72 & $10.9 \mathrm{~b}$ & $7.2 \mathrm{bc}$ & $21.9 \mathrm{bcd}$ & $18.3 \mathrm{bc}$ \\
\hline & Gu 74 & $10.1 \mathrm{~b}$ & $5.0 \mathrm{abc}$ & $20.0 \mathrm{abc}$ & $12.8 \mathrm{ab}$ \\
\hline & Gu 75 & $5.4 \mathrm{a}$ & $3.2 \mathrm{a}$ & $12.0 \mathrm{a}$ & $8.8 \mathrm{a}$ \\
\hline & Gu 86 & $6.6 \mathrm{ab}$ & $7.5 \mathrm{bc}$ & $15.7 \mathrm{ab}$ & $21.1 \mathrm{bc}$ \\
\hline & Boyne & $9.8 \mathrm{ab}$ & $4.1 \mathrm{ab}$ & $15.0 \mathrm{ab}$ & $13.2 \mathrm{ab}$ \\
\hline & Comet & $10.8 \mathrm{~b}$ & $8.1 \mathrm{c}$ & $16.9 \mathrm{abc}$ & $20.2 \mathrm{bc}$ \\
\hline & Chilcotin & $26.2 \mathrm{c}$ & $26.9 \mathrm{~d}$ & 32.3 de & $36.8 \mathrm{~d}$ \\
\hline & Comox & $21.8 \mathrm{c}$ & $31.5 \mathrm{~d}$ & $34.4 \mathrm{e}$ & $36.9 \mathrm{~d}$ \\
\hline & Mean & 11.8 & 11.1 & 21.0 & 21.4 \\
\hline
\end{tabular}

${ }^{\mathrm{z}}$ Mean separation within columns by LSMEANS, $P \leq 0.05$.

considered significantly more hardy than 'Boyne', the hardiest cultivar in the study (Table 1).

Overall dieback was higher when expressed as percent bud number $($ mean $=16.5 \%)$ than as percent cane length $($ mean $=8.1 \%)$ (Table 2). In this particular study, bud counts excluded those buds below the mid-portion of the cane (i.e., excludes those buds that did not develop below the most distal lateral). Therefore, percentage dieback based on bud number is an overestimate relative to that calculated by length in which the entire cane was used in the measurement. Regardless, little difference occurred in the ranking among the genotypes when cane dieback was expressed in terms of percent length or percent bud number (Table 1) and the two 
measures of dieback were strongly correlated (rank correlation: $\tau$ $=0.87, P=0.0005)$.

The lack of development of the buds in the mid-portion of the raspberry cane may be caused by a number of other factors in addition to winter damage. Generally, only two thirds of raspberry nodes develop fruiting laterals, primarily because the apical dominance of the upper buds limits the development of the lower ones (Jennings, 1988). For the same reason, in the sub-terminal region of the cane, nodes with good lateral production were often followed by less successful nodes (Jennings, 1987).

Winter 1989-90 was more cold-challenging than Winter 1988-89 at CRS and Montreal. In 1989, December had a lower average daily minimum temperature $(-14.3 \mathrm{C})$ than that of the coldest month of Winter 1988-89 (-11.8C). This was followed by milder conditions in January 1990, when temperatures increased above 0C at CRS and Montreal. The warm period may have caused a certain degree of dehardening (Brierley and Landon, 1946). Another decline in temperature occurred during February when the minimum daily temperature dropped to $-8.8 \mathrm{C}$.

Bud death within the mid-portion of the cane exhibited genotype $\times$ year interactions. For example, during the mild winter of 1989, 'Comox' had $33.4 \%$ bud death in the midportion of the cane compared to 1990 when it had the highest percentage $(35.7 \%)$ of bud death (Table 3 ).

Measuring cane maturity. The early cessation of cane extension growth was not related to a greater cane hardiness in this study. For example, no significant correlation existed between genotype ranking and time of cessation of cane extension growth in the fall of 1989 and dieback at CRS in 1990 whether calculated as percent length or as percent bud number. Previous reports have indicated an association between extension growth and hardiness (Van Adrichem, 1966 and 1970). However, Van Adrichem (1970) reported a relationship between dieback and cane growth rate in the fall, but not with the time of growth cessation.

Early leaf drop was not correlated with a greater hardiness in this study. For example, Gu 75 and 'Boyne' suffered little dieback at CRS in 1990, but were among the last cultivars to lose their leaves the previous fall. Van Adrichem (1970) found an association between the extent of leaf drop and winter hardiness while Fejer and Spangelo (1973) found no association. The lack of association may be due to difference in methodology. In the present study, measurements similar to Van Adrichem's (1970) were taken.

\section{Controlled freezing tests}

Controlled freezing tests produced $\mathrm{LT}_{40} \mathrm{~s}$ that differed among the various test dates. Significant genotype by date interactions also occurred for each of the two viability tests.

$\mathrm{LT}_{50}$ values were determined to show agreement with $\mathrm{LT}_{40}$ values (Table 4) and to allow comparisons with those published. Hummer et al. (1995) reported stem $\mathrm{LT}_{50}$ 's in January of -28C for 'Boyne' and $-22 \mathrm{C}$ for 'Chilcotin'; our comparable values are -38.9C and -35.8C (Table 3). These differences are likely due to development of greater hardiness in our area. Warmund and George (1990) reported that buds of Minnesota-grown raspberry were very hardy, e.g., $\mathrm{LT}_{50}$ for 'Canby' was $-39 \mathrm{C}$ compared to $-25 \mathrm{C}$ reported for buds on Oregongrown wood (Hummer et al., 1995).

Visual assessment. Average $\mathrm{LT}_{40} \mathrm{~s}$ calculated from the visual assessment of both stems and buds decreased as the season progressed during the fall as the plant acclimated, reached the lowest temperature by midwinter ( 8 Jan.) and then increased as the plant deacclimated in the spring. The mean $\mathrm{LT}_{40} \mathrm{~s}$ of the combined dates differed significantly and were as follows: for stems: $-17.4 \mathrm{C}$ (fall, 16 Oct., 30 Oct., 15 Nov.); -29.7C (midwinter, 8 Jan., 21 Feb.); and -
23.7C (spring, 13 Mar., 31 Mar., 16 Apr.); buds:-15.7C (fall, 16 Oct., 30 Oct., 15 Nov.), -28.6C (midwinter, 8 Jan.), and-18.1C (spring, 13 Mar., 31 Mar., 16 Apr.). Such patterns of relative hardiness throughout the year have been reported for raspberry (Pacholak, 1978; Warmund and George, 1990) apple (Emmert and Howlett, 1953) and filbert (Hummer et al., 1986).

Mean $\mathrm{LT}_{40} \mathrm{~s}$ indicated that the stems of Gu 74 and 'Boyne' ranked among the most cold tolerant during the three fall dates (Fig. 1). Stems of 'Comox' fluctuated in ranking as one of the least cold tolerant on 16 Oct. to one of the most cold tolerant on 31 Oct. Stems of 'Chilcotin' were the least hardy on all three fall dates. Hummer et al. (1995) also determined that stems of 'Boyne' were more hardy than those of 'Chilcotin'. In midwinter, stems did not differ greatly in cold hardiness.

During the spring dates, stems of 'Chilcotin' were among the least cold tolerant on $31 \mathrm{Mar}$. and $16 \mathrm{Apr}$. but had an intermediate ranking on 13 Mar. After 21 Feb. stems deacclimated at different rates which were not consistent with their hardiness levels in the field. Stems of 'Boyne' lost freezing resistance more rapidly than other cultivars. On 16 Apr. only 'Chilcotin' had significantly less freezing tolerance than 'Boyne' (Fig. 1).

Similar trends were observed for $\mathrm{LT}_{40} \mathrm{~s}$ of buds as for stems. In contrast, 'Chilcotin' and 'Comox' buds had less resistance to freezing at most dates compared to other genotypes (Fig. 2). The difference was not as great as for stem sections (Fig. 1). Buds of $\mathrm{Gu}$ 74 and $\mathrm{Gu} 86$ deacclimated slower than other genotypes and retained a higher level of freezing resistance. This is a valuable trait in northern temperate climates where early spring temperatures often fluctuate and reach very low levels.

The visual assessment of injury gave the greatest separation among the genotypes in the spring. Genotypes differed more in the cold tolerance of their buds than of their stems. Average bud $\mathrm{LT}_{40} \mathrm{~S}$ over the entire winter ranged $9.4 \mathrm{C}$ compared to a range of only 2.9C for the stems (Figs. 1 and 2). Warmund and George (1990) assessed the cold tolerance of buds of a number of raspberry cultivars and also found the greatest cultivar differences to occur in the spring. Stems were also more cold tolerant than buds in this and other studies (Hummer et al., 1995).

Conductivity method. The assessment of injury by electrolyte leakage resulted in significant differences among dates and genotypes, and a significant date by genotype interaction.

Table 3. Percent bud death within the midportion and for the total cane of 10 raspberry genotypes averaged for two locations (Cambridge Research Station and Montreal) for two winters (1988-89 and 1989-90).

\begin{tabular}{lccccc}
\hline & \multicolumn{2}{c}{ Midcane bud death $(\%)$} & & \multicolumn{2}{c}{ Total cane bud death $(\%)$} \\
\cline { 2 - 3 } \cline { 6 - 7 } Genotype & 1989 & 1990 & & 1989 & 1990 \\
\hline Gu 62 & $40.9 \mathrm{bc}^{\mathrm{z}}$ & $19.0 \mathrm{bc}$ & & $47.1 \mathrm{~cd}$ & $35.4 \mathrm{de}$ \\
Gu 63 & $43.3 \mathrm{c}$ & $28.5 \mathrm{~cd}$ & & $43.9 \mathrm{c}$ & $34.7 \mathrm{de}$ \\
Gu 72 & $31.5 \mathrm{abc}$ & $16.9 \mathrm{ab}$ & & $39.7 \mathrm{c}$ & $25.6 \mathrm{bc}$ \\
Gu 74 & $35.4 \mathrm{abc}$ & $14.4 \mathrm{ab}$ & & $40.6 \mathrm{c}$ & $24.3 \mathrm{bc}$ \\
Gu 75 & $27.7 \mathrm{ab}$ & $9.7 \mathrm{a}$ & & $29.0 \mathrm{a}$ & $16.5 \mathrm{a}$ \\
Gu 86 & $24.6 \mathrm{a}$ & $15.1 \mathrm{ab}$ & & $31.5 \mathrm{ab}$ & $27.1 \mathrm{bc}$ \\
Boyne & $46.9 \mathrm{c}$ & $14.6 \mathrm{ab}$ & & $41.8 \mathrm{c}$ & $21.7 \mathrm{ab}$ \\
Comet & $36.0 \mathrm{abc}$ & $10.0 \mathrm{a}$ & & $39.3 \mathrm{bc}$ & $28.4 \mathrm{~cd}$ \\
Chilcotin & $46.7 \mathrm{c}$ & $23.7 \mathrm{bc}$ & & $56.0 \mathrm{~d}$ & $41.3 \mathrm{e}$ \\
Comox & $33.4 \mathrm{abc}$ & $35.7 \mathrm{~d}$ & & $42.1 \mathrm{c}$ & $56.1 \mathrm{f}$ \\
Cultivar mean & & & & \\
$\quad$ CRS & $44.2 \mathrm{c}$ & $9.6 \mathrm{a}$ & & $40.6 \mathrm{~b}$ & $21.2 \mathrm{a}$ \\
Montreal & $29.1 \mathrm{~b}$ & $29.2 \mathrm{~b}$ & & $40.9 \mathrm{~b}$ & $40.9 \mathrm{~b}$ \\
\hline
\end{tabular}

${ }^{\mathrm{z}}$ Mean separation within columns for cultivars by LSMEANS, $\mathrm{P}<0.05$. ${ }^{y}$ Mean separation for both years within a category by LSMEANS, $\mathrm{P}<0.05$. 

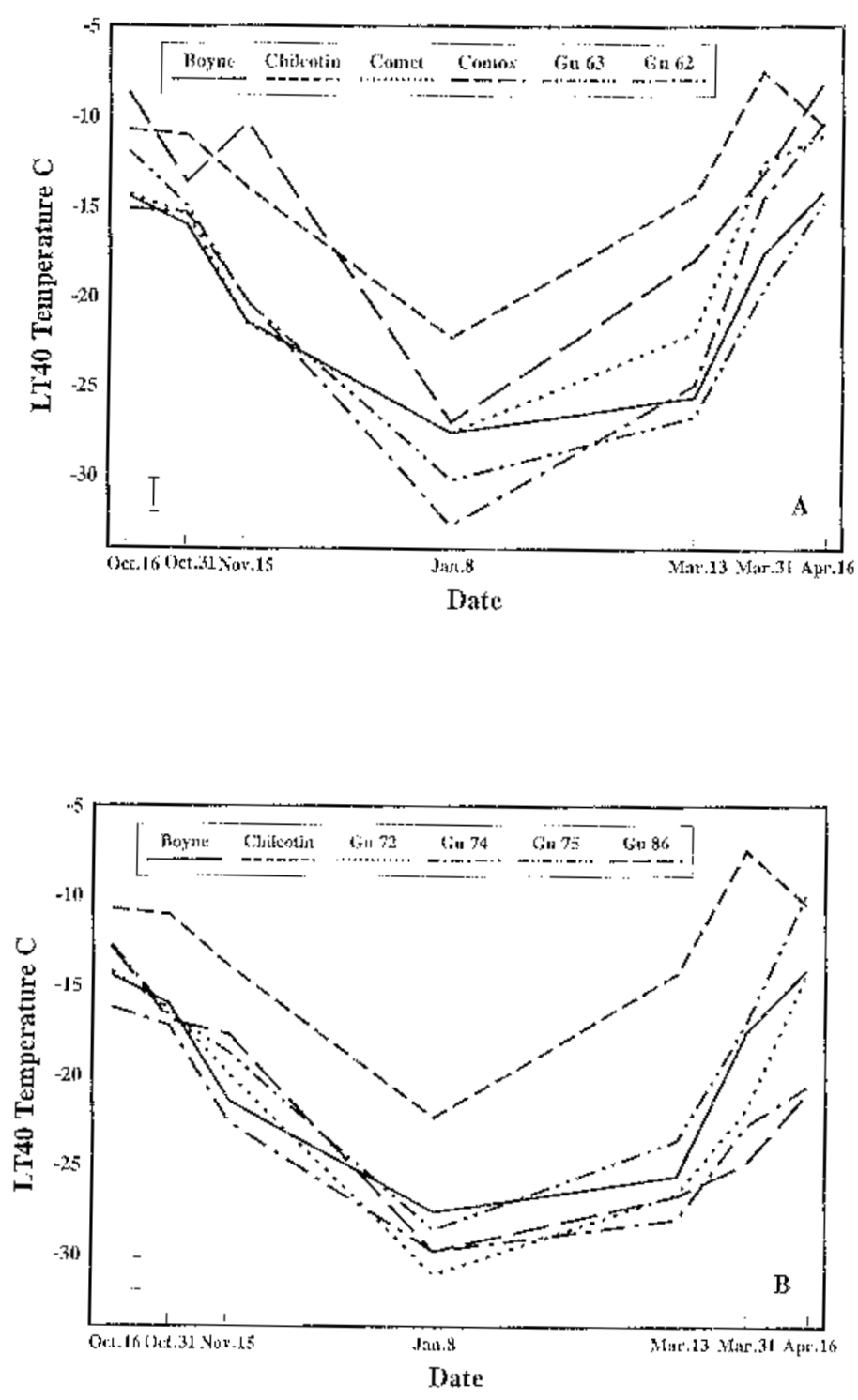

Fig 2. Mean $\mathrm{LT}_{40} \mathrm{~s}$ of buds of 10 raspberry genotypes after controlled freezing and visual assessment of tissue browning, CRS, 1989-90. The bar on each graph (bottom left) represents the minimum difference required for significance between two means at a comparison wise error rate of $\alpha=0.05$.
Average $\mathrm{LT}_{40} \mathrm{~s}$ from the conductivity assessment indicated that injury occurred at the highest temperature in the fall (16 Oct.), and at the lowest temperature in midwinter (8 Jan.) (Table 4). The $\mathrm{LT}_{40} \mathrm{~s}$ for the two test dates in the spring (31 Mar. and 16 Apr.) were not significantly different. Plants in the spring were $10.8 \mathrm{C}$ more cold tolerant than on 16 Oct., but $6.1 \mathrm{C}$ less hardy than on 8 Jan.

A significant genotype by date interaction occurred for $\mathrm{LT}_{40} \mathrm{~S}$ over the four dates (Table 4) indicating conductivity measurements could identify different acclimation and deacclimation patterns between these genotypes. The significant interaction was not surprising since all genotypes except Gu 72 had similar $\mathrm{LT}_{40} \mathrm{~s}$ on 16 Oct. 1989 and were variable on the other three dates. Gu 72 had the lowest $\mathrm{LT}_{40}$ values on 16 Oct. 1989 and 8 Jan. 1990 (-15.9 and 31.7 respectively) but had a $\mathrm{LT}_{40}$ similar to a non-hardy cultivar such as 'Comox'. In contrast, 'Boyne' had a LT T0 $_{40}$ that was consistently low at each of the four dates.

Controlled freezing tests $v$ s. field results. The different methods of field assessment of genotype ranking were mostly significantly correlated with each other (Table 5) except for time of cane leaf drop and cessation of cane extension growth in the fall (see above). Cold hardiness field assessment using tip dieback (Table 2), as either percent length or bud number, was very good (82\% significant correlations, Table 5). Genotype rankings from field survival were poorly correlated with laboratory freezing of the stems with only 1 of 24 correlations significant (Table 5). Warmund and George (1990) also reported that hardiness of red raspberry buds determined from $\mathrm{T}_{50}$ values did not always agree with field evaluations. Reasons for poor agreement between field and laboratory measurements may include time of sampling, type of bud selected, freezing test protocol and genotype. In this study lack of correlation may be due to genotype as suggested by the differential performance of $\mathrm{Gu} 75$. This genotype often had the least dieback in the field (see above) but generally showed more injury than many of the other genotypes after laboratory freezing. By excluding $\mathrm{Gu} 75$ from the analysis, increased the significant correlations from $4.2 \%$ to $16.7 \%$. Field genotype rankings of overall dieback at Montreal and CRS for both years (Table 1) and dieback at CRS in 1990 (Table 2) were correlated with genotype rankings from both spring dates of the conductivity assessment (Table 4) (rank correlations: overall dieback, $\tau=0.50, P=0.05$ and $\tau=0.65, P=0.01$ for 31 Mar. and 16 Apr., respectively; dieback at CRS in 1990, $\tau=$ $0.55, P=0.04$ for 31 Mar. and $\tau=0.59, P=0.03$ for 16 Apr.).

More significant correlations between controlled freezing tests and field results could be found by combining data. For example,

Table 4. Mean $\mathrm{LT}_{40} \mathrm{~s}$ and $\mathrm{LT}_{50} \mathrm{~s}$ of stems of 10 raspberry genotypes after controlled freezing and conductivity assessment of viability on four dates.

\begin{tabular}{|c|c|c|c|c|c|c|c|c|}
\hline \multirow[b]{3}{*}{ Genotype } & \multicolumn{8}{|c|}{ Date } \\
\hline & \multicolumn{2}{|c|}{16 Oct. 1989} & \multicolumn{2}{|c|}{8 Jan. 1990} & \multicolumn{2}{|c|}{31 Mar. 1990} & \multicolumn{2}{|c|}{16 Apr. 1990} \\
\hline & $\mathrm{LT}_{40}$ & $\mathrm{LT}_{50}$ & $\mathrm{LT}_{40}$ & $\mathrm{LT}_{50}$ & $\mathrm{LT}_{40}$ & $\mathrm{LT}_{50}$ & $\mathrm{LT}_{40}$ & $\mathrm{LT}_{50}$ \\
\hline Gu 62 & $-12.6 b^{\mathrm{Z}}$ & -15.5 & $-25.3 \mathrm{~cd}$ & -32.8 & $-24.7 \mathrm{ab}$ & -30.9 & $-21.5 \mathrm{bcd}$ & -27.5 \\
\hline Gu 63 & $-12.8 \mathrm{ab}$ & -15.2 & $-29.0 \mathrm{abc}$ & -35.7 & $-26.0 \mathrm{a}$ & -33.4 & $-23.7 \mathrm{abc}$ & -31.2 \\
\hline Gu 72 & $-15.9 \mathrm{a}$ & -19.7 & $-31.7 \mathrm{a}$ & -40.0 & $-21.6 c$ & -27.4 & $-22.6 \mathrm{abc}$ & -28.0 \\
\hline $\mathrm{Gu} 74$ & $-11.7 b$ & -14.7 & $-31.1 \mathrm{ab}$ & -37.5 & $-25.1 \mathrm{a}$ & -31.5 & $-25.3 \mathrm{a}$ & -36.4 \\
\hline Gu 75 & $-11.6 b$ & -13.8 & $-28.9 a b c$ & -37.7 & $-23.2 \mathrm{abc}$ & -30.4 & $-21.9 \mathrm{bcd}$ & -27.2 \\
\hline $\mathrm{Gu} 86$ & $-10.6 \mathrm{~b}$ & -14.4 & $-28.0 \mathrm{bcd}$ & -36.3 & $-23.4 \mathrm{abc}$ & -31.1 & $-23.7 a b c$ & -30.0 \\
\hline Boyne & $-11.6 \mathrm{~b}$ & -14.5 & $-30.6 a b$ & -38.9 & $-24.9 \mathrm{a}$ & -30.7 & $-24.0 \mathrm{ab}$ & -30.2 \\
\hline Comet & $-12.0 \mathrm{~b}$ & -14.8 & $-28.0 \mathrm{bcd}$ & -34.3 & $-21.7 b c$ & -29.0 & $-20.7 \mathrm{~cd}$ & -26.5 \\
\hline Chilcotin & $-11.3 b$ & -14.4 & $-26.9 \mathrm{~cd}$ & 35.8 & $-21.7 \mathrm{bc}$ & -26.5 & $-19.0 \mathrm{~d}$ & -24.7 \\
\hline Comox & $-11.1 \mathrm{~b}$ & -14.7 & $-30.4 a b$ & -37.6 & $-20.5 c$ & -24.3 & $-22.1 b c$ & -27.5 \\
\hline Mean & -12.1 & -15.2 & -29.0 & -36.7 & -23.3 & -29.5 & -22.4 & -28.9 \\
\hline
\end{tabular}

${ }^{\mathrm{z}}$ Mean separation within columns by LSMEANS, $P<0.05$. 
Table 5. Comparisons of correlation coefficients $(\tau)$ for field and laboratory assessments of cold hardiness of raspberry genotypes.

\begin{tabular}{llc}
\hline \hline Data source & Type of correlation pairs & $\begin{array}{c}\text { No. of significant correlations } \\
(\% \text { of total })\end{array}$ \\
\hline Table 1 & Field assessments & 3 of 3(100) \\
Table 2 & Field assessments & 23 of $28(82)$ \\
Table 3 & Field assessments & 2 of $6(33)$ \\
Tables 1, 2, and 3 & Field assessments & 77 of $105(73)$ \\
Tables 2 and 3 (1990 data only) & Field and laboratory assessments & 1 of 24 (4.2) \\
Table 4 & (10 genotypes) & 4 of 24 (16.7) \\
\hline
\end{tabular}

${ }^{\mathrm{z}}$ Significant at $P \leq 0.05$.

genotype rankings of total cane bud death in 1990 and bud death within the mid-portion of the cane in 1990 (Table 3) were correlated with those of bud hardiness as determined in the laboratory for the combined fall dates $(\tau=0.51, P=0.02)$ and for 30 Oct. ( $\tau$ $=0.64, P=0.005$ for total cane bud death; $\tau=0.56, P=0.01$ for bud death within the midportion of the cane). Again, when Gu 75 was excluded from the analysis, significant correlations existed between the laboratory and field results. For example, genotype ranking of total cane bud death in 1990 (Table 2) was correlated with that of the visual assessment of buds on all individual spring and fall dates and an average of all dates (fall: $\tau=0.67, P=0.006$; spring: $\tau=0.50, P=0.03$ ).

It is not surprising that the relative hardiness of the genotypes during the spring and the fall was best correlated with field observations, because the onset and rate of fall acclimation and spring deacclimation are more crucial in the determination of the winter survival of raspberries than their maximum hardiness level attained in midwinter (Brierley and Landon, 1946; Jennings et al., 1972; Pacholak, 1978). Emmert and Howlett (1953) also found that the relative hardiness of 55 apple cultivars was best determined in the fall.

Controlled freezing test protocol may influence correlations with field measurements. Hummer et al. (1995) have suggested one protocol to estimate maximum midwinter cold hardiness of raspberry. Because of the limitations of the freezing tests reported by Warmund and George (1990) and in this study, further development of a standardized protocol for hardiness in raspberry breeding and selection is warranted.

The ability of raspberry tissue to reharden after short periods of warm weather is recognized as being of major importance in the winter hardiness of raspberries. The primary cause of bud damage in six raspberry cultivars in Nova Scotia was attributed to extreme fluctuations in winter temperatures (Craig and Aalders, 1966). Brierley and Landon (1946) attributed winter injury in 'Latham' raspberry to drops in temperature early in the fall before sufficient hardiness developed, and to dehardening during periods of warm temperatures. However, the controlled freezing tests used in this study would not be able to detect the extent of dehardening of the various genotypes unless sampled after a period of warmer temperatures during the winter months. This is a major weakness of using controlled freezing tests to measure hardiness in areas where unseasonal warming trends are common.

\section{Literature Cited}

Brierley, W.G. and R.H. Landon. 1946. Some relationships between rest period, rate of hardening, loss of cold resistance, and winter injury in the 'Latham' raspberry. Proc. Amer. Soc. Hort. Sci. 47:224-234.

Brooks, R.M. and H.P. Olmo. 1972. Register of new fruit and nut varieties, second ed. Univ. of California Press, Berkeley.
Craig, D.L. and L.E. Aalders. 1966. Winter injury and yielding ability of six red raspberry varieties under two systems of culture in Nova Scotia. Can. J. Plant Sci. 46:73-76.

Cummins, J.H. 1994. Register of new fruit and nut varieties. Brooks and Olmo List 36. HortScience 29:942-969.

Daubeny, H.A. 1978. Chilcotin red raspberry. Can. J. Plant Sci. 58:279-282.

Daubeny, H.A. 1987. 'Chilliwack' and 'Comox' red raspberries. HortScience 22:1343-1345.

Emmert, F.H. and F.S. Howlett. 1953. Electrolytic determinations of the resistance of fifty-five apple varieties to low temperatures. Proc. Amer. Soc. Hort. Sci. 62:311-318.

Fejer, S.O. 1973. Genotype $\times$ year interactions and ecovalence in raspberry selection. Can. J. Genet. Cytol.15:226-229.

Fejer, S.O. and L.P.S. Spangelo. 1973. Red raspberry yield components and their relation to mechanical harvesting. J. Amer. Soc. Hort. Sci. 98:432-436.

Hummer (Brainerd), K., H.B. Lagerstedt, and S.K. Kim. 1986. Filbert acclimation, maximum cold hardiness, and deacclimation. J. Amer. Soc. Hort. Sci. 111:474-482.

Hummer, K., L.H. Fuchigami, V. Peters, and A. Bell. 1995. Cold hardiness in Rubus. Fruit Var. J. 49:52-58.

Jennings, D.L. 1987. Some effects of secondary dormancy and correlative inhibition on the development of lateral bud of raspberry canes (Rubus idaeus L.). Hort. Res. 27:119-129.

Jennings, D.L. 1988. Raspberries and blackberries: Their breeding, diseases, and growth. Academic Press, London.

Jennings, D.L., E. Carmichael, and J.J. Costin. 1972. Variation in the time of acclimation of raspberry canes in Scotland and Ireland and its significance for hardiness. Hort. Res. 12:187-200.

Khanizadeh, S., D. Buszard, M.A. Fanous, and C.G. Zarkadas. 1989. Effect of crop load on seasonal variation in chemical composition and spring frost hardiness of apple flower buds. Can. J. Plant Sci. 69:1277-1284.

Levitt, J. 1980. Responses of plants to environmental stresses. vol. I. Chilling, freezing, and high temperature stresses. Academic Press, New York.

Pacholak, E. 1978. Factors affecting frost tolerance of raspberry canes. Acta Hort. 81:97-101.

Quamme, H.A. and C. Stushnoff. 1983. Resistance to environmental stress, p. 242-253 In: J.N. Moore and J. Janick (eds.). Methods in fruit breeding. Purdue Univ. Press, West Lafayette, Ind.

Sakai, A. and W. Larcher. 1987. Frost survival of plants, responses, and adaptation to freezing stress. Springer-Verlag, Berlin.

Stushnoff, C. 1972. Breeding and selection methods for cold hardiness in deciduous fruit crops. HortScience 7:10-13.

Ure, C.R. and J.W. Morrison. 1962. Notes on 'Boyne' and 'Killarney' red raspberries. Can. J. Plant Sci. 42:543-544.

Van Adrichem, M.C.J. 1966. An association between late summer growth rate and fall frost injury in red raspberries. HortScience 1:94-95.

Van Adrichem, M.C.J. 1970. Assessment of winter hardiness in red raspberries. Can. J. Plant Sci. 50:181-187.

Warmund, M.R. and M.F. George. 1990. Freezing survival and supercooling in primary and secondary buds of Rubus spp. Can. J. Plant Sci. 70:893-904.

Zatylny, Annette, M., J.T.A. Proctor, and J.A. Sullivan. 1993. In vitro screening of four red raspberry genotypes for cold hardiness. HortScience 28: 740-741. 